\title{
Peran Pemerintah Daerah Dalam Memberdayakan Masyarakat Untuk Meningkatkan Pembangunan Daerah
}

\author{
Adlin Damanik \\ Universitas Islam Negeri Sumatera Utara \\ (E-mail: friendly_rhaida@yahoo.com)
}

\begin{abstract}
Development with multiple dimensions, covering social, economic, ecological and institutional aspects. Underdevelopment and underdevelopment that occur in an area is an objective condition that must be considered in each development process. However the development process produces consequences. Efforts to overcome the backwardness of society can be done through fundamental efforts, namely sectoral, segmental (part) and spatial (location / space / place). The paradigm of the community empowerment approach is the key word to get out of the problem of underdevelopment in the context of regional development. In the process of community empowerment, local governments are required to formulate clear and directed concepts for the direction of development and development of regions with diverse potentials to be used and utilized towards the real prosperity and happiness of the people in the region.
\end{abstract} Keywords: Local Government and Community Empowerment

Abstrak: Pembangunan berdimensi jamak, meliputi aspek sosial, ekonomi, ekologi dan institusi. Keterbelakangan dan ketertinggalan yang terjadi pada suatu daerah merupakan kondisi objektif yang harus dipikirkan dalam setiap proses pembangunan. Bagaimanapun proses pembangunan menghasilkan konsekuensi. Upaya menanggulangi keterbelakangan masyarakat dapat dilakukan melalui usaha yang mendasar, yakni secara sektoral, segmental (bagian) dan spatial (lokasi/ruang/tempat). Paradigma pendekatan pemberdayaan masyarakat menjadi kata kunci untuk keluar dari problem keterbelakangan dalam konteks pembangunan daerah. Dalam proses pemberdayaan masyarakat, pemerintah daerah dituntut memformulasi konsep yang jelas dan terarah bagi arah pembangunan dan pengembangan daerah dengan beragam potensi yang dimilikinya untuk kemudian digunakan dan dimanfaatkan menuju kemakmuran dan kebahagiaan masyarakat di daerah secara nyata.

Kata Kunci: Pemerintah Daerah dan Pemberdayaan Masyarakat. 
172 Adlin Damanik, Peran Pemerintah Daerah Dalam Memberdayakan Masyarakat Untuk Meningkatkan Pembangunan Daerah

Jurnal At-Taghyir : Jurnal Dakwah dan Pengembangan Masyarakat Desa

Volume 1 Nomor 2 Juni 2019, h. 171-186

\section{A. Pendahuluan}

Paradigma pembangunan tidak hanya bermuka ekonomi. Ikhtiar meningkatkan pendapatan nasional penting, namun tidak berjalan sendiri. Perlu disertai oleh adanya perombakan berbagai segi kehidupan masyarakat supaya pembangunan mampu meniadakan ketimpangan, mengurangi ketidakmerataan dan menghalau kemiskinan absolut. Tujuan pembangunan adalah untuk meningkatkan kualitas hidup manusia secara terencana, gradual, bertahap, komprehensif, holistik, sistemik, bertanggungjawab dan berkelanjutan dengan melibatkan peran serta seluruh elemen warga masyarakat. Pembangunan adalah usaha merubah kondisi kehidupan, tingkat kesejahteraan dan keadilan masyarakat agar menjadi lebih baik. Dalam definisi yang dibuat oleh United Nations disebutkan bahwa pembangunan adalah orientasi dan kegiatan usaha yang tanpa akhir, "developing is not a static concept, it is continuously changing".

Kompleksitas permasalahan diperbesar oleh faktor wilayah permasalahan yang semakin luas. Semakin terbatas pendapatan seseorang, semakin sederhana kebutuhannya. Tetapi semakin meningkat pendapatan seseorang, semakin meluas kebutuhannya. Dengan demikian, pembangunan merupakan proses tanpa akhir, suatu kontinuitas perjuangan mewujudkan idealitas dan realitas yang akan terus berlangsung sepanjang kurun sejarah. Proses pembangunan sebenarnya adalah suatu perubahan sosial budaya. Agar pembangunan menjadi proses yang dapat bergerak maju, perlu dilakukan atas kekuatan sendiri (self sustaining proces) tergantung kepada manusia dan struktur sosialnya. Pembangunan bukan hanya dikonsepsikan sebagai usaha pemerintah an sich. Pembangunan tergantung pada suatu innerwill, proses emansipasi diri serta partisipasi kreatif melalui proses pendewasaan.

Dalam banyak kepustakaan tentang pembangunan, terdapat beberapa pendekatan dan teori. Menyebut beberapa di antaranya adalah growth theory, rural development theory, agro first, basic needs, dan lain sebagainya. Teori-teori pembangunan itu memuat berbagai pendekatan ilmu sosial yang berusaha menangani masalah keterbelakangan. Teori pembangunan benar-benar lepas landas hanya setelah diketahui bahwa persoalan pembangunan di Dunia Ketiga bersifat khusus dan secara kualitatif berbeda dari "transisi orisinil". Sepanjang evolusinya, teori pembangunan menjadi semakin kompleks dan nondisipliner. Dengan demikian, tidak akan ada definisi baku 
173 Adlin Damanik, Peran Pemerintah Daerah Dalam Memberdayakan Masyarakat Untuk Meningkatkan Pembangunan Daerah

Jurnal At-Taghyir : Jurnal Dakwah dan Pengembangan Masyarakat Desa

Volume 1 Nomor 2 Juni 2019, h. 171-186

dan final mengenal pembangunan, yang ada hanyalah usulan mengenai apa yang seharusnya diimplikasikan oleh pembangunan dalam konteks tertentu.

Pembangunan didefinisikan secara amat kontekstual dan harus merupakan konsep terbuka, yang harus didefisinikan kembali secara terus menerus, seiring dengan semakin mendalamnya pemahaman kita tentang proses, maupun sejalan dengan munculnya persoalan baru yang perlu dipecahkan dengan pembangunan. Sejak awal, sesungguhnya teori pembangunan terkait erat dengan strategi pembangunan, yakni perubahan struktur ekonomi dan pranata sosial yang diupayakan untuk menemukan solusi yang konsisten dan langgeng bagi persoalan yang dihadapi para pembuat keputusan dalam suatu masyarakat. Pembangunan sering diartikan sebagai rumusan implementasi dari kebijakan pembangunan yang beroperasi secara spesifik di setiap daerah. Sedangkan kebijakan pembangunan merupakan suatu pendekatan untuk menangkap isu-isu yang lebih spesifik dalam rangka merealisasikan tujuan atau sasaran pembangunan. Pertimbangan yang mendasari rumusan kebijakan dan program pembangunan sering bersifat kompleks. Kebijakan dan implementasi program pembangunan merupakan hasil kompromi di antara stakeholder sesuai dengan kepentingannya masing-masing, dari aspek politik, ekonomi, sosial dan lingkungan.

Pengalaman dan perjalanan pembangunan suatu negara bersifat spesifik. Faktor penentu pembangunan senantiasa dikaitkan dengan momentum atau keputusan politik aktual pada masanya yang terkait secara langsung atau tidak langsung dengan pembangunan. Kebijakan pembangunan pada dasarnya merupakan rumusan dari kesepakatan atau kompromi kepentingan atau harapan seluruh stakeholder yang diwujudkan dalam suatu keputusan atau peraturan. Hal ini berarti seluruh stakeholder memiliki kesamaan pandangan, setidaknya tentang isu-isu penting yang ingin ditangkap dan dioperasikan. Peran atau fungsi pelaku pembangunan atas dasar pengalaman dari waktu ke waktu memperlihatkan hal-hal penting. Pertama, pelaku versus program. Keberhasilan pembangunan tidak dapat dilepaskan dengan lahirnya bisnis-bisnis baru. Makin kuat lingkungan memberikan dorongan atas munculnya bisnis-bisnis yang mencerminkan keberhasilan pembangunan. Namun pada saat ini, faktor-faktor kondusif untuk lingkungan bisnis sangat kompleks. Umumnya pelaku bisnis tidak lagi melihat program, tetapi bagaimana menciptakan dan mengantisipasi celah-celah bisnis baik 
174 Adlin Damanik, Peran Pemerintah Daerah Dalam Memberdayakan Masyarakat Untuk Meningkatkan Pembangunan Daerah

Jurnal At-Taghyir : Jurnal Dakwah dan Pengembangan Masyarakat Desa

Volume 1 Nomor 2 Juni 2019, h. 171-186

secara tidak langsung dari program ataupun secara langsung di antara pelaku bisnis itu sendiri. Kedua, kepentingan publik versus perorangan. Dengan semakin besar peranan bisnis di dalam perekonomian ditemukan kecenderungan perubahan perilaku pada birokrasi maupun pelaku bisnis (atau interaksinya) dari yang sebelumnya mementingkan sektor-sektor publik menjadi (ke dalam) sektor-sektor perorangan. Sepanjang perilaku demikian mendorong kompetisi secara sehat di antara pelaku bisnis, ekspansi bisnis dapat diperluas, biaya sosial (social cost) dapat ditekan, maka kepentingan pribadi (private interest) dari birokrasi tersebut dapat diterima.

Dalam kaitannya dengan Peran Pemerintah Daerah Dalam Memberdayakan Masyarakat Untuk Meningktakan Pembangunan Daerah, setidaknya ada tiga masalah besar yang harus diidentifikasi yang sekaligus sebagai motivasi atau tujuan penting yang mendasari berlangsungnya pembangunan itu sendiri, yaitu:

1. Meningkatkan kesempatan kerja. Hampir setiap isu yang dirumuskan dalam kebijakan pembangunan senantiasa mengarah pada penggunaan tenaga kerja seoptimal mungkin. Alasan yang mendasarinya adalah pengangguran merupakan suatu biaya kebatalan (opportunity cost) yang mengakibatkan produksi nasional berkurang dari yang seharusnya (GNP gap).

2. Memperbaiki fiskal. Motivasi kedua ini merupakan konsekuensi dari berbagai peran pemerintah dalam pembangunan, antara lain sebagai pelaku, pengendali, pengawas, pemelihara, pengamanan, dan pemulih (perehabilitasi) dari proses, hasil, dampak, dan tujuan pembangunan. Energi (government expenditure) untuk menjalankan peran tersebut harus diambil dari seluruh stakeholder dan shareholder dalam bentuk pajak dan insentif lainnya.

3. Pembangunan daerah miskin. Sangat dimaklumi bahwa tidak semua stakeholder menerima atau tersentuh hasil pembangunan. Mereka umumnya tetap berada dalam ketertinggalan, keterbelakangan, kebodohan dan kemiskinan. Sebagai suatu bentuk ketidakefisienan, hal-hal tersebut harus terus-menerus direhabilitasi melalui kebijakan dan program yang terarah dan terintegrasi.

Dalam perkembangan selanjutnya, muncul berbagai pendekatan menyangkut terma-terma kajian tentang pembangunan. Satu di antaranya adalah mengenai isu pembangunan daerah. Secara luas, pembangunan daerah diartikan sebagai suatu upaya 
175 Adlin Damanik, Peran Pemerintah Daerah Dalam Memberdayakan Masyarakat

Untuk Meningkatkan Pembangunan Daerah

Jurnal At-Taghyir : Jurnal Dakwah dan Pengembangan Masyarakat Desa

Volume 1 Nomor 2 Juni 2019, h. 171-186

merumuskan dan mengaplikasikan kerangka teori ke dalam kebijakan ekonomi dan program pembangunan yang di dalamnya mempertimbangkan aspek daerah dengan mengintegrasikan aspek sosial dan lingkungan menuju tercapainya kesejahteraan yang optimal dan berkelanjutan (Nugroho dan Dahuri, 2004). Pembangunan daerah pada dasarnya merupakan proses yang dinamis, rumit, dan berdimensi jamak. Sekalipun seluruh stakeholder sudah dilibatkan, belum tentu hasilnya memuaskan. Dengan kata lain senantiasa lahir hasil-hasil yang tidak diinginkan (eksternalitas), terutama berkenaan dengan pengangguran, subsidi salah sasaran, dan kemiskinan. Itulah sebabnya dasar konsepsional pembangunan daerah diarahkan pada pembangunan yang secara efektif mampu menghadapi permasalahan pembangunan di masing-masing wilayah. Pengertian dan penerapan pembangunan daerah pada umumnya dikaitkan dengan kebijakan ekonomi atau keputusan politik yang berhubungan dengan alokasi secara spasial dari kebijakan pembangunan nasional secara keseluruhan. Dengan demikian, kesepakatan nasional yang menyangkut sistem politik dan pemerintahan, atau aturan mendasar lainnya, sangat menentukan pengertian dari pembangunan daerah.

Menurut Cullis dan Jones (dalam Nugroho dan Dahuri, 2004), pembangunan daerah sangat tepat diimplementasikan dalam perekonomian yang mengandalkan pengelolaan sumber-sumber daya publik (common and public resources), antara lain sektor kehutanan, perikanan, atau pengelolaan wilayah perkotaan. Hal ini diyakini pengambilan keputusan secara otonomi akan mampu menyederhanakan kompleksitas pengelolaan sumber daya, mengintensifkan pembinaan lingkungan (free-rider) atau masalah moral (moral hazard). Sebagai implikasi lanjutannya, pembangunan daerah memberikan pilihan sesuai dengan keragaman karakteristik wilayah dan solusinya serta alternatif sistem transaksi (pasar) mana yang dikehendaki. Perencanaan pembangunan daerah semakin relevan dalam mengimplemen tasikan kebijakan ekonomi dalam aspek kewilayahan. Dalam kerangka pengembangan daerah, perlu dibatasi pengertian "wilayah" yakni ruang permukaan bumi dimana manusia dan makhluk lainnya dapat hidup dan beraktivitas. Menurut Undang-Undang Nomor 24 Tahun 1992 tentang Penataan Ruang, wilayah diartikan sebagai kesatuan geografis beserta segenap unsur terkait yang batas dan sistemnya ditentukan berdasarkan aspek administratif dan atau aspek fungsional. Dalam kerangka pembangunan nasional, perencanaan pengembangan 
176 Adlin Damanik, Peran Pemerintah Daerah Dalam Memberdayakan Masyarakat Untuk Meningkatkan Pembangunan Daerah

Jurnal At-Taghyir : Jurnal Dakwah dan Pengembangan Masyarakat Desa

Volume 1 Nomor 2 Juni 2019, h. 171-186

wilayah dimaksudkan untuk memperkecil perbedaan pertumbuhan kemakmuran antar wilayah atau antar daerah. Di samping itu, diusahakan untuk memperkecil perbedaan kemakmuran antara perkotaan dan perdesaan (Jayadinata, 1999).

Perencanaan daerah di berbagai negara tidak sama, tergantung kepada kehidupan ekonomi dan masalah yang dihadapi. Secara historis setidaknya terdapat tiga pendekatan perencanaan daerah (Jayadinata, 1999):

1. Perencanaan daerah yang memusatkan perhatiannya kepada masalah kota yang bersifat sosial. Pelaksanaannya meliputi perbaikan bagian kota yang keadaan yang telah rusak dan tidak memenuhi standar, pemugaran kota, pembuatan kota setelit untuk membantu meringankan kota industri yang terlalu padat penduduknya. Titik berat perencanaan wilayah semacam ini ditujukan pada kota yang besar dan wilayah sekelilingnya (hinterland) yang dapat menunjang kota dalam perencanaan kota dan wilayah.

2. Perencanaan daerah yang memusatkan perhatiannya kepada wilayah yang penduduknya banyak menganggur dan dalam keadaan stagnasi industri (wilayah khusus). Dalam wilayah seperti ini, pemerintah perlu mengatur intensif pembiayaan, pengaturan rangsangan untuk prasarana industri, pengaturan konsesi pajak dan sebagainya, sehingga industri tertentu dapat berlokasi di wilayah itu.

3. Perencanaan dareah yang memperhatikan wilayah pedesaan, dengan pengembangan tanah bagi sektor pertanian dan rekreasi (perencanaan pedesaan dan wilayah). Hal ini dilakukan untuk memperkecil perbedaan kemakmuran antara pedesaan dan perkotaan.

Untuk meratakan pembangunan, harus digunakan pendekatan perwilayahan atau regionalisasi, yaitu pembagian wilayah nasional dalam satuan wilayah geografi, sehingga setiap bagian mempunyai sifat tertentu yang khas (dapat juga menurut satuan daerah tatapraja atau daerah administrasi). Di samping itu, diperlukan juga desentralisasi yaitu kebijaksanaan yang diputuskan oleh pemerintah regional dan lokal. Dalam desentralisasi itu harus terdapat koordinasi yang baik. Sekalipun mekanisme pengambilan keputusan otonomi terbukti sangat sesuai dengan pengelolaan sumberdaya alam dan lingkungan, kegiatan pembangunan daerah untuk beberapa hal masih memerlukan mekanisme pengambilan keputusan yang lebih tinggi atau menggunakan 
177 Adlin Damanik, Peran Pemerintah Daerah Dalam Memberdayakan Masyarakat Untuk Meningkatkan Pembangunan Daerah

Jurnal At-Taghyir : Jurnal Dakwah dan Pengembangan Masyarakat Desa

Volume 1 Nomor 2 Juni 2019, h. 171-186

azas sentralisasi. Hal ini didasari karena kenyataan menunjukkan permasalahan lingkungan cenderung bersifat global melintasi wilayah, atau disebabkan oleh alasanalasan berikut (Schwab, 1998):

1. Terdapat aliran eksternalitas sebagai biaya dan manfaat dari alokasi sumber daya alam dan akibat-akibatnya (terutama dalam bentuk polusi) yang dilakukan di luar wilayah.

2. Ada suatu manfaat unik yang ditimbulkan oleh kondisi lingkungan tanpa membedakan wilayah, misalnya kenyamanan dan keindahan taman nasional.

3. Ada standar yang seragam dan terkoordinasi sehingga kebijakan lingkungan menjadi lebih efisien dan efektif.

4. Ada kekhawatiran kompetisi antara wilayah sebagai akibat beragamnya standar kebijakan.

Itulah sebabnya menjadi penting bahwa pembangunan daerah memerlukan perencanaan dan koordinasi yang terpadu, secara vertikal dan horizontal untuk mengantisipasi aliran eksternalitas secara spasial dan akumulatif. Dengan demikian, kebijakan dan program pembangunan daerah yang disusun tidak hanya dapat memberi panduan yang terarah dan efisien bagi pemecahan permasalahan, tetapi lebih jauh memberi jaminan akan keberlanjutan sistem produksi dalam wilayah.

\section{B. Konsep Pemberdayaan Masyarakat}

Pendekatan pemberdayaan masyarakat dalam pembangunan bukan hal yang sama sekali baru, tetapi sebagai konsep yang tersusun dan sebagai strategi dalam pembangunan memang relatif belum terlalu lama dibicarakan. Keberdayaan dalam konteks masyarakat adalah kemampuan individu yang bersenyawa dengan individuindividu lainnya dalam masyarakat dan membangun keberdayaan masyarakat yang bersangkutan. Keberdayaan masyarakat itu terdiri unsur-unsur yang memungkinkan suatu masyarakat bertahan (survive); dan dalam pengertian yang dinamis mengembangkan diri dan mencapai kemajuan.

Memberdayakan masyarakat dapat dilakukan dengan cara memperkuat unsurunsur kebudayaan untuk meningkatkan harkat dan martabat lapisan masyarakat yang dalam kondisi sekarang tidak mampu dengan hanya mengandalkan pada kekuatannya sendiri untuk melepaskan diri dari perangkap kemiskinan dan keterbelakangan. Dengan 
178 Adlin Damanik, Peran Pemerintah Daerah Dalam Memberdayakan Masyarakat Untuk Meningkatkan Pembangunan Daerah

Jurnal At-Taghyir : Jurnal Dakwah dan Pengembangan Masyarakat Desa

Volume 1 Nomor 2 Juni 2019, h. 171-186

kata lain memberdayakan adalah memampukan dan memandirikan masyarakat. Mengikuti alur pikir di atas, bahwa upaya memberdayakan masyarakat harus dilakukan melalui tiga tahap. Pertama, menciptakan suasana atau iklim yang memungkinkan potensi masyarakat berkembang (enabling). Titik tolaknya adalah pengenalan bahwa setiap manusia, setiap masyarakat memiliki potensi yang dapat dikembangkan. Pemberdayaan adalah upaya membangun daya itu, dengan mendorong, memotivasi dan membangkitkan kesadaran akan potensi yang dimilikinya serta berupaya untuk mengembangkannya. Kedua, memperkuat potensi atau daya yang dimiliki oleh masyarakat (empowering). Penguatan ini meliputi langkah-langkah nyata, dan menyangkut penyediaan berbagai masukan, serta pembukaan akses kepada berbagai peluang yang akan membuat masyarakat menjadi semakin berdaya. Ketiga, memberdayakan dalam arti melindungi. Dalam proses pemberdayaan harus dicegah yang lemah menjadi bertambah lemah, oleh karena kekurangberdayaan menghadapi yang kuat. Perlindungan dan pemihakan kepada yang lemah amat mendasar sifatnya dalam konsep pemberdayaan masyarakat. Melindungi tidak berarti mengisolasi dan menutupi dari interaksi, karena hal itu bukan akan memperkuat, tetapi justeru melemahkan. Melindungi harus dilihat sebagai upaya untuk mencegah terjadinya persaingan yang tidak seimbang, serta eksploitasi yang kuat atas yang lemah.

Pemberdayaan masyarakat bukan membuat masyarakat menjadi semakin tergantung pada berbagai program pemberian dan belas kasihan. Karena pada dasarnya setiap apa yang dinikmati harus dihasilkan atas usaha sendiri. Pemberdayaan pada dasarnya menyangkut lapisan bawah atau lapisan masyarakat miskin yang dinilai tertindas oleh sistem dan dalam struktur sosial. Upaya pemberdayaan itu sendiri menyangkut beberapa segi: 
179 Adlin Damanik, Peran Pemerintah Daerah Dalam Memberdayakan Masyarakat Untuk Meningkatkan Pembangunan Daerah

Jurnal At-Taghyir : Jurnal Dakwah dan Pengembangan Masyarakat Desa

Volume 1 Nomor 2 Juni 2019, h. 171-186

1. Penyadaran dan peningkatan kemampuan untuk menemukenali (identifikasi) persoalan dan permasalahan yang menimbulkan kesulitan hidup dan penderitaan yang dialami oleh masyarakat yang hendak diberdayakan.

2. Penyadaran tentang kelemahan maupun potensi yang dimiliki, sehingga menimbulkan dan meningkatkan kepercayaan kepada diri sendiri untuk keluar dari persoalan dan guna memecahkan permasalahan serta mengembangan diri.

3. Meningkatkan kemampuan manajemen sumberdaya yang telah ditemukenali. Secara eksternal, pemberdayaan memerlukan upaya-upaya advokasi kebijakan ekonomi-politik yang pada pokoknya bertujuan untuk membuka akses golongan bawah, lemah dan tertindas terhadap sumber daya yang dikuasai oleh golongan kuat.

Untuk membangkitkan partisipasi masyarakat sehingga berkemauan dan memiliki rasa kerelaan dalam pemberdayaan masyarakat hanya dapat diupayakan dengan cara membangunkan sikap positif di hati mereka. Sikap positif yang mendasari kemauan untuk ikut mengambil bagian dalam pengembangan masyarakat hanya bisa dibangkitkan kalau orang sudah memperoleh pengetahuan yang cukup tentang selukbeluk program kegiatan yang ditawarkan untuk diikutsertakan. Dengan kata lain, aspek afektif masyarakat hanyalah akan dapat dikembangkan apabila aspek kognisinya berhasil digarap terlebih dahulu. Pemberdayaan masyarakat merupakan proses belajar dan pencerahan masyarakat yang terus menerus dilakukan untuk meningkatkan kualitas hidup, harkat dan martabatnya lewat kegiatan emansipasi dan pencerahan sosial yang terencana, terarah dan terkendali secara berkelanjutan. Sebagai proses belajar yang bersifat partisipatif dan emansipatoris, peberdayaan masyarakat merupakan proses yang dinamis yang senantiasa melakukan pembaruan diri dengan upaya penajaman analisis, alat analisis serta sasarannya. Demikian pula ia senantiasa mengupayakan pengembangan konsep, metode dan teknik-teknik serta manajemen.

Paling tidak telah berkembang tiga model kelompok pemberdayaan masyarakat.

1. Kelompok filantropis. Kelompok ini memandang bahwa masalah kemiskinan masyarakat dapat diubah melalui upaya kemanusiaan, tanpa mengubah kelembagaan dan struktur kemasyarakatannya. Upaya kemanusiaan ini secara evolutif akan meningkatkan kondisi sosial, ekonomi dan budaya masyarakat 
180 Adlin Damanik, Peran Pemerintah Daerah Dalam Memberdayakan Masyarakat Untuk Meningkatkan Pembangunan Daerah

Jurnal At-Taghyir : Jurnal Dakwah dan Pengembangan Masyarakat Desa

Volume 1 Nomor 2 Juni 2019, h. 171-186

sebagai upaya kedermawanan (karikatif) untuk membantu kebutuhan desa, dengan mendirikan rumah sakit, sekolah dan sebagainya.

2. Kelompok reformis. Kelompok ini beranggapan bahwa untuk meningkat kan kondisi masyarakat pada saat ini tidak perlu dengan mengubah atau mengganti sistem sosial yang ada berikut kelembagaan dengan sistem maupun kelembagaan yang baru, melainkan cukup dengan mereformasinya.

3. Kelompok revolusioner. Menurut kelompok ini bahwa kemiskinan yang mendalam, kebodohan dan keterbelakangan budaya pada masyarakat secara fundamental merupakan akibat dari sistem sosial yang ada dan kelembagaannya yang merupakan alat untuk melestarikan keterbe-lakangan tersebut. Oleh karenanya, kelompok ini berupaya untuk melakukan perubahan secara radikal terhadap struktur sosial ekonomi masyarakat.

Tujuan utama program pemberdayaan masyarakat adalah dalam rangka meningkatkan produktivitas, memperbaiki kualitas hidup penduduk serta memperkuat kemandirian. Ada enam elemen dasar yang melekat dalam program pemberdayaan semacam ini. Pertama, pembangunan pertanian dengan mengutamakan padat karya (labour intenvise). Kedua, memperluas kesempatan kerja. Ketiga, intensifikasi tenaga kerja skala kecil, dengan cara mengembangkan industri kecil di perdesaan. Keempat, mandiri dan meningkatkan partisipasi dalam proses pengambilan keputusan. Kelima, mengembangkan daerah perkotaan yang mampu memberikan daya dukung bagi masyarakat. Keenam, membangun kelembagaan yang mampu melakukan koordinasi proyek multisektor. Permasalahan menahun yang dialami oleh sebagian penduduk, menyebabkan terjadinya kemiskinan karena tidak mampu memanfaatkan peluang yang ada. Potensi dan peluang ekonomi yang muncul sebagai dampak dari pelaksanaan pembangunan hanya dapat dimanfaatkan oleh kelompok kaya dan mampu. Keadaan ini jika dibiarkan terus berlangsung akan menyebabkan kesenjangan. Penanggulangannya dapat ditempuh antara lain melalui pemberdayaan dan pemihakan terhadap masyarakat miskin yang diwujudkan melalui upaya yang berdampak pada peningkatkan kualitas dan kemampuan masyarakat miskin, berupa peningkatan motivasi, keterampilan, penguasaan aspek manajemen dan teknologi. 
181 Adlin Damanik, Peran Pemerintah Daerah Dalam Memberdayakan Masyarakat

Untuk Meningkatkan Pembangunan Daerah

Jurnal At-Taghyir : Jurnal Dakwah dan Pengembangan Masyarakat Desa

Volume 1 Nomor 2 Juni 2019, h. 171-186

Ujung tombak dari prioritas pemberdayaan masyarakat miskin adalah pengembangan ekonomi rakyat yang dimaknai sebagai sistem ekonomi yang mengutamakan partisipasi dari masyarakat, sehingga masyarakat sebagai pelaku pembangunan dapat menikmati hasil-hasil pembangunan sesuai dengan kerja dan sumbangan yang diberikannya pada proses pembangungan yang tengah berlangsung. Terbentuknya ekonomi rakyat merupakan prakondisi dari terciptanya masyarakat yang maju, mandiri, sejahtera dan adil. Perwujudan ekonomi rakyat membutuhkan beberapa prasyarat, yaitu: (a) sumberdaya manusia yang beriman, berkualitas, dan berdaya, (b) kelembagaan pemerintah dan masyarakat desa yang mampu menjalankan dan mengawal pelaksanaan pembangunan perdesaan, (c) prasarana yang merata dan sesuai dengan kebutuhan pembangunan, (d) pemantapan sistem monitoring dan evaluasi

\section{Alternatif yang Dapat Dilakukan Pemerintah Daerah}

Secara garis besar pembangunan dibagi atas dua kategori, yaitu pembangunan nasional dan pembangunan regional (daerah). Pembangunan nasional merupakan cerminan dari pembangunan di tingkat regional (daerah). Pembangunan yang mengarah pada bidang sektoral misalnya adalah pembangunan gedung sekolah, pembangunan pusat perdagangan (pasar), pembangunan koperasi (KUD), pembangunan bidang kesehatan (Puskesmas) dan pembangunan-pembanguan sektoral lainnya. Dalam setiap proses pembangunan mengundang peran pemerintah untuk ikut aktif di dalamnya, karena sesungguhnya perencana dan pelaksana pembangunan itu sendiri adalah pemerintah dengan melibatkan seluruh komponen masyarakat yang ada. Tetapi tetap saja pemerintah daerah menjadi sangat sentral posisinya dalam hal memajukan masyarakat di seluruh wilayah kekuasaannya.

Hubungan pemerintah daerah dengan pemberdayaan masyarakat merupakan persoalan yang menyangkut bagaimana posisi atau kedudukan pemerintah daerah yang dikonsepsikan oleh birokrat dalam proses pembangunan, yaitu bagaimana dan sejauhmana peran yang dapat dimainkan oleh pemerintah dalam mengintrodusir konsep-konsep pembangunan sehingga mampu memberikan kontribusi kualitatif dalam upaya pemberdayaan masyarakat. Dalam kaitannya dengan pemberdayaan masyarakat tersebut, maka peran strategis pemerintah daerah secara sosio kultural harus mampu memberikan penjelasan yang dapat dimengerti secara gamblang serta mampu 
182 Adlin Damanik, Peran Pemerintah Daerah Dalam Memberdayakan Masyarakat Untuk Meningkatkan Pembangunan Daerah

Jurnal At-Taghyir : Jurnal Dakwah dan Pengembangan Masyarakat Desa

Volume 1 Nomor 2 Juni 2019, h. 171-186

memberikan "makna mendalam" dari hakikat pembangunan itu sendiri, dalam bentuk sosialisasi yang memiliki daya kejelasan dan daya jelajah bagi penyelesaian masalah sosial kultural yang dihadapi oleh masyarakat. Berdasarkan konsepsi pemberdayaan sebagai usaha peningkatan kualitas hidup manusia yang manusiawi, maka peran pemerintah daerah (terlepas dari apapun predikatnya), secara eksistensial hendaknya mampu berperan sebagai berikut:

1. Sebagai mobilisator pembangunan. Peranan ini bermakna bahwa pemerintah niscaya mampu memberi rumusan etos kerja yang dinamis kreatif sekaligus religius yang sanggup secara sosial ekonomi dan sosial budaya melahirkan tingkat produktifitas kerja yang tinggi sehingga memperlancar proses pembangunan daerah.

2. Memberi orientasi pembangunan. Secara sosial budaya pemerintah daerah memberikan arah, titik tolak, kriteria, way of perception, serta warna nilai yang jelas, pasti, manusiawi, religius sehingga pada gilirannya proses pembangunan daerah berjalan sebagaimana mestinya tanpa kendala kultural maupun religius, muaranya dapat mencapai tujuan pembangunan masyarakat.

3. Sebagai komunikator pembangunan. Dalam hal ini, pemerintah daerah harus sanggup memberikan pesan-pesan pembangunan yang komunikatif dan dialogik. Mensosialisasikan teologi pembangunan diharapkan dapat menghindari distorsi komunikasi religius yang menjadi kendala pembangunan masyarakat.

4. Sebagai justifikator pembangunan. Untuk mampu memfungsikan dirinya sebagai pemberi legitimasi ke arah terbukanya proses pembangunan, maka pemerintah daerah dituntut untuk berani memberikan restu yang legitimate secara pasti, tegas, tentang apa yang benar, boleh dan apa yang salah, atau tidak boleh dilaksanakan dalam proses pembangunan.

5. Sebagai evaluator pembangunan. Dalam konteks ini pemerintah daerah dituntut sanggup memberikan evaluasi secara terhadap upaya pembangunan yang tengah berlangsung.

Proses memperkenalkan atau mengkomunikasikan segala sesuatu yang asing kepada suatu kelompok masyarakat, baik berupa ide atau benda teknologi, disebut sebagai diffusi. Secara teoritis paling tidak terdapat lima unsur penting yang saling 
183 Adlin Damanik, Peran Pemerintah Daerah Dalam Memberdayakan Masyarakat Untuk Meningkatkan Pembangunan Daerah

Jurnal At-Taghyir : Jurnal Dakwah dan Pengembangan Masyarakat Desa

Volume 1 Nomor 2 Juni 2019, h. 171-186

berkaitan dalam proses diffusi tersebut, yakni: (a) pembawa ide (agents atau sources); (b) penerima (adopters); (c) saluran (channels) yang ditempuh; (d) jenis ide atau teknologi yang akan diperkenalkan; dan (e) waktu yang digunakan (time). Secara umum kegiatan yang dapat dilakukan oleh pemerintah daerah sebagai problem solving masalah pemberdayaan masyarakat, dikategorikan kepada tiga jenis pendekatan, yaitu:

1. Pendekatan yang memandang masyarakat yang menjadi sasaran proses diffusi sebagai objek semata. Dalam pendekatan ini masyarakat yang menjadi sasaran pemberdayaan dipandang sebagai "benda mati", tanpa perlu diberi kesempatan untuk melakukan penilaian apakah ide yang disosialisasikan kepada mereka berguna atau tidak.

2. Pendekatan dengan memberikan rangsangan dan motivasi kepada masyarakat yang dijadikan sasaran diffusi untuk memikirkan problem utama yang mereka hadapi dan diberikan kesempatan untuk memikirkan dan menemukan cara pemecahan terbaik. Model pendekatan ini menjadikan masyarakat sebagai subjek sasaran.

3. Penggabungan pendekatan pertama dan kedua. Pada hal-hal tertentu masyarakat diperlakukan sebagai objek, akan tetapi pada kesempatan lain dipandang sebagai subjek, tergantung situasi dan kondisi. Pendekatan terakhir ini selain memandang masyarakat yang perlu dituntun ke arah jalan yang tepat, juga diberikan kesempatan yang luas untuk memikirkan dan merancang pengembangan potensi diri mereka sendiri.

Para pekerja sosial yang bertugas melakukan pemberdayaan masyarakat seringkali merasa telah paham terhadap kebutuhan masyarakat yang menjadi sasaran mereka, padahal kesimpulan yang diambil tersebut sering keliru. Akibatnya program yang telah dirancang dengan biaya yang mahal tidak efektif mencapai sasaran. Akhirnya seringkali terjadi pemutarbalikan fakta bahwa masyarakat yang menjadi sasaran tidak tanggap terhadap ide-ide pemberdayaan, dan masyarakat tidak mau menerima perubahan. Dalam konteks ini pemerintah daerah yang bertugas dalam melakukan pemberdayaan masyarakat untuk membangun daerah, perlu memahami kondisi psikologis berupa social needs dan social interest dari masyarakat yang menjadi sasaran. Kecuali itu, akan sangat arif bila proses pembangunan itu dilakukan melalui pendekatan lokal (kultural) yang tidak bertentangan dengan paradigma dan adat istiadat 
184 Adlin Damanik, Peran Pemerintah Daerah Dalam Memberdayakan Masyarakat Untuk Meningkatkan Pembangunan Daerah

Jurnal At-Taghyir : Jurnal Dakwah dan Pengembangan Masyarakat Desa

Volume 1 Nomor 2 Juni 2019, h. 171-186

masyarakat. Melalui pemaknaan bahasa, budaya serta kebiasaan yang berlaku dalam kehidupan masyarakat lokal akan sangat memberi warna tersendiri bagi upaya melempangkan proses pembangunan yang berlangsung pada suatu daerah.

Secara sektoral misalnya pemerintah daerah bertanggungjawab melakukan pemilihan terhadap cabang-cabang ekonomi mana yang pantas untuk dikembangkan pada suatu kondisi masyarakat yang terbelakang, peran pemerintah daerah jelas sangat vital, ikut intervensi dalam menentukan arah kebijakan potensi ekonomi apa saja yang pantas dikembangkan dan mendapat prioritas pada masyarakat terbelakang tersebut. Selanjutnya fasilitas dan kemudahan dalam pemberdayaan ekonomi masyarakat juga perlu mendapat perhatian pemerintah daerah apakah dalam bentuk subsidi, memberi bantuan (pinjaman) dan sebagainya untuk mendorong supaya sektor ekonomi berkembang pesat pada masyarakat terbelakang tersebut. Menyangkut segmental, memang terdapat perbedaan tingkat populasi pada masyarakat. Tidak semua masyarakat memiliki tingkat populasi yang seragam. Oleh karenanya pertimbangan pasar, sumber daya manusia juga menjadi pilihan objektif pemerintah untuk mengembangkan suatu daerah yang terbelakang tersebut. Pada sisi spatial (lokasi, ruang, tempat) yang menjadi perbincangan adalah bagaimana kualitas daerah tersebut untuk mengembangkan sektor ekonomi, pertanian, industri dan sebagainya. Apakah memang daerah tersebut memiliki potensi ekonomi yang memadai, apakah daerah tersebut memiliki tingkat resiko yang tinggi bagi kelangsungan sebuah industri dan sebagainya? Pertimbangan-pertimbangan rasional seperti di atas perlu dipikirkan untuk membangun daerah terbelakang tersebut sambil melakukan evaluasi bagaimana cara mencari jalan keluarnya.

Menyangkut kesatuan wilayah bagian untuk perbandingan antara daerah perlu dipertimbangkan intervensi yang selaras yang dilakukan pemerintah daerah yaitu menyangkut tiga hal: Pertama, bagaimana pemecahan masalah; kedua, bagaimana melewati masalah tersebut; dan ketiga, bagaimana pemanfaatan potensi wilayah untuk pengembangan daerah tersebut. Pemecahan masalah mempertimbangkan tingkat marginalisasi daerah, seperti misalnya ada daerah terpencil yang sulit dijangkau secara fisik baik menyangkut sulitnya sarana maupun prasarana jalan ke daerah itu, sulitnya melakukan hubungan komunikasi ke daerah itu, sampai kepada aksebilitas masyarakat terhadap proses pembangunan yang dilakukan untuk pengembangan wilayah. Dalam hal 
185 Adlin Damanik, Peran Pemerintah Daerah Dalam Memberdayakan Masyarakat Untuk Meningkatkan Pembangunan Daerah

Jurnal At-Taghyir : Jurnal Dakwah dan Pengembangan Masyarakat Desa

Volume 1 Nomor 2 Juni 2019, h. 171-186

inilah peran pemerintah daerah untuk ikut melakukan intervensi, misalnya membangun jalan, membangun jembatan, memperbaiki sarana dan prasarana yang mendukung proses kemajuan masyarakat, upaya meningkatkan pendidikan, meluruskan persepsi masyarakat terhadap proses pembangunan yang tengah dan terus dilaksanakan, semuanya tentu saja ditujukan untuk kepentingan dan kemakmuran masyarakat.

Perbedaan tingkat pendapatan daerah juga merupakan masalah dalam pembangunan. Terjadinya perbedaan tingkat pendapatan tersebut disebabkan banyak faktor. Misalnya potensi daerah yang memberi kontribusi bagi PAD nya, letak geografis dan potensi alam, kemampuan sumber daya manusia dalam pengelolaan sumber daya alam yang tersedia, sampai kepada persoalan tingkat kejujuran dan kecilnya praktek KKN yang terjadi pada suatu daerah, tentu saja hal ini sangat subjektif untuk diperbincangkan. Tetapi tetap saja asumsi itu sangat releven untuk diperdebatkan mengingat ada daerah yang potensinya luar biasa tetapi dalam laporan yang diberikan pendapatan asli daerah tersebut kecil, ini disebabkan ketidakjujuran aparat pelaksana di setiap daerah.

Upaya yang dilakukan pemerintah untuk mengatasi permasalahan di atas, tentu saja ikut berperan aktif untuk memberi penjelasan, pelatihan dan bimbingan yang dapat merangsang aparat di tingkat daerah untuk berkompetisi dengan daerah lain. Sambil mencari sumber potensi daerah lain yang tentu saja masih belum banyak tergali diakibatkan kurangnya sarana dan prasarana sampai kepada rendahnya tingkat teknologi yang kita miliki. Hal ini tentu saja sangat berpengaruh terhadap tingkat perbedaan pendapatan pada daerah.

\section{Penutup}

Melewati masalah-masalah yang dihadapi tentu saja kendala dan tantangan banyak ditemukan. Tetapi peran pemerintah daerah untuk menanggung resiko sedemikian besar, tidak saja merupakan sebuah keharusan tetapi bagaimana pemerintah merangkul seluruh komponen masyarakat yang ada untuk include dalam proses pembangunan daerah dan pemberdayaan masyarakat. Pemerintah darah dituntut agar tidak terlalu arogan memaksakan keinginan terhadap model pengembangan daerah yang diinginkan karena menyangkut biaya, resiko dan balikan yang diharapkan. Tetapi harus lebih fleksibel mempertimbangkan need society dan interest society, sehingga terjadi 
186 Adlin Damanik, Peran Pemerintah Daerah Dalam Memberdayakan Masyarakat

Untuk Meningkatkan Pembangunan Daerah

Jurnal At-Taghyir : Jurnal Dakwah dan Pengembangan Masyarakat Desa

Volume 1 Nomor 2 Juni 2019, h. 171-186

gayung bersambut terhadap konsep pembangunan daerah dengan apa yang menjadi kebutuhan dan ketertarikan masyarakat. Sehingga masyarakat dengan sendirinya terangsang untuk ikut memikirkan dan melakukan perubahan menuju pemberdayaan masyarakat dan daerahnya.

\section{Daftar Kepustakaan}

Chambers, Robert. 1983. Rural Development: Putting the Last First. London: Longman.

Chirzin, M. Habib. 1995. "Pengembangan Masyarakat Suatu Upaya Pencerahan Sosial", dalam Ade Ma'ruf WS dan Zulfan Heri. Muhammadiyah dan Pemberdayaan Rakyat. Yogyakarta: Pustaka Pelajar.

Desai, A. R. 1980. "Three Schools of Rural Reconstruction", dalam Kamla Bhasin dan Vimala R. Reading on Poverty, Politics and Development. Roma; Freedom from Hunger Campaign/Action for Development, FAO.

Hettne, Bjorn. 2001. Teori Pembangunan dan Tiga Dunia. Jakarta: Gramedia Pustaka Utama.

Jayadinata, Johara T. 1999. Tata Guna Tanah dalam Perencanaan Pedesaan, Perkotaan dan Wilayah. Bandung: ITB Bandung.

Kartasasmita, Ginandar. 1995. "Pemberdayaan Masyarakat dalam Rangka Pengembangan Ekonomi Rakyat", dalam Bestari, Nomor 20 tahun VIII Agustus-Desember 1995.

Nugroho, Iwan dan Rokhmin Dahuri. 2004. Pembangunan Wilayah: Perspektif Ekonomi, Sosial dan Lingkungan. Jakarta: LP3ES.

Rahardjo, M. Dawam. 1995. "Muhammadiyah dan Pemberdayaan Ekonomi Umat", dalam Bestari, Nomor 20 tahun VIII Agustus-Desember 1995.

Sairin, Sjafri. 1995. "Beberapa Catatan tentang Upaya Pengembangan Masyarakat", dalam dalam Ade Ma'ruf WS dan Zulfan Heri. Muhammadiyah dan Pemberdayaan Rakyat. Yogyakarta: Pustaka Pelajar.

Sumodiningrat, Gunawan. 1999. "Butir-Butir Pemikiran Strategi Penghapusan Kemiskinan dalam Pembangunan Pedesaan", dalam Hasan Basri (ed). Pembangunan Ekonomi Rakyat di Pedesaan sebagai Strategi Penanggulangan Kemiskinan. Jakarta: Bina Rena Pariwara.

Usman, Sunyoto. 1988. Pembangunan dan Pemberdayaan Masyarakat. Yogyakarta: Pustaka Pelajar.

Wignjosoebroto, Soetandyo. 1995. "Mendayagunakan Metode Reinforcement dalam Praktik Untuk Mengaktifkan Partisipasi Masyarakat dalam rangka Mesukeskan Program Pembangunan di Perdesaan", dalam Bestari, Nomor 20 tahun VIII Agustus-Desember 1995. 